Sari Pediatri, Vol. 7, No. 1, Juni 2005: 19-25

\title{
Penyakit Alergi Saluran Napas yang Menyertai Asma
}

\author{
Lily Irsa
}

Asma merupakan penyakit yang mempunyai predisposisi genetik, dipengaruhi oleh faktor lingkungan prenatal dan pasca natal. Sebagaimana penyakit atopi lain seperti rinitis alergi dan dermatitis atopi dalam perjalanannya asma dipengaruhi oleh adanya sensitisasi primer oleh alergen dan pajanan berikutnya yang akan meningkatkan produksi IgE spesifik. Penyakit asma diketahui sering bersamaan dengan penyakit alergi saluran napas lainnya. Hal ini karena saluran napas atas dan saluran napas bawah merupakan saluran yang berhubungan dan bila terjadi gangguan pada saluran napas atas akan mempengaruhi saluran napas bawah.

Kata kunci: asma, rhinitis, sinusitis, alergi

$\mathrm{P}$ enyakit alergi merupakan hasil dari interaksi antara faktor predisposisi genetik atopi dengan alergen lingkungan, infeksi dan polutan. Faktor lingkungan memegang peranan besar pada sensitisasi awal seseorang yang mempunyai bakat atopi dan akan menentukan perkembangan gejala klinis serta derajat beratnya penyakit. ${ }^{1}$ Kondisi alergi umumnya rinitis alergi, asma, dan dermatitis atopi mempunyai jalur imunopatologi yang sama. Perjalanan penyakit alergi merupakan konsep yang memperlihatkan bahwa penyakit alergi saling berhubungan dan tampilan penyakit alergi berubah menurut umur.

Hubungan asma dengan sinusitis telah diketahui dan dijelaskan pada literatur medik lebih dari 70 tahun. Hampir 80\% pasien asma menderita rinitis dan lebih $50 \%$ pasien dengan penyakit sinus juga menderita asma. ${ }^{2,3}$ Khususnya pasien dengan asma berat memperlihatkan abnormalitas yang jelas pada sken sinus paranasal. ${ }^{4}$ Apakah rinosinusitis merupakan faktor presipitasi asma bronkial masih diperdebatkan. ${ }^{2}$

\footnotetext{
Alamat korespondensi:

Dr. Lily Irsa, Sp.A.

Bagian Ilmu Kesehatan Anak. FK-USU/RS H Adam Malik, Medan.

Jl. Bunga Lau no. 17, Medan 20136.

Telepon: 061-836 0405, 836 0143. Fax. 061-836 1721.
}

Tulisan ini bertujuan untuk membahas asma dan penyakit alergi saluran napas yang sering timbul bersamaan serta patofisiologinya.

\section{Anatomi dan fisiologi saluran napas}

Anatomi saluran napas dari hidung sampai ke alveoli berbeda. Rongga hidung digambarkan sebagai ruangan yang kaku, dibatasi oleh tulang-tulang wajah, dan perubahan saluran napas disebabkan oleh perubahan ketebalan jaringan mukosa. Mukosa hidung banyak mengandung pembuluh darah yang membentuk sinusoid. Pembuluh darah ini dipengaruhi oleh sistem saraf di sekitar rongga hidung sehingga mudah melebar dan menyempit. Sebaliknya bronkus dan cabangcabangnya mempunyai cincin kartilago yang tidak lengkap dan dilengkapi oleh otot polos. Makin ke distal kartilago ini makin kecil, akhirnya hilang pada bronkiolus. 5

Fungsi saluran napas manusia dibagi menjadi dua bagian, yaitu sebagai penghantar dan pertukaran udara. Hidung dan saluran napas atas merupakan pertahanan pertama sistem pernapasan melawan partikel di udara dan iritan. Hidung berfungsi untuk menghangatkan, melembabkan dan menyaring udara, sebagai organ penciuman, konservasi uap air serta suhu terhadap 
udara lingkungannya. Fungsi menghangatkan, melembabkan, dan menyaring udara ini pada dasarnya untuk melindungi saluran napas bagian bawah terhadap pengaruh dingin, kering, maupun udara kotor karena polusi. ${ }^{5}$

Obstruksi saluran napas dapat terjadi karena vasodilatasi, edema jaringan, sumbatan mukus, dan kontraksi otot polos. Bila terjadi sumbatan pada hidung maka pernapasan dilakukan melalui mulut sehingga peran hidung untuk humidifikasi akan hilang atau berkurang. Biasanya hal tersebut menimbulkan masalah terutama bila udara yang dihirup dingin dan kering karena akan mengeringkan sekret dan menimbulkan spasme bronkus di saluran napas bagian bawah. ${ }^{5}$

\section{Perjalanan penyakit alergi}

Atopi atau predisposisi genetik untuk memproduksi IgE spesifik setelah pajanan alergen merupakan komponen dari penyakit atopi seperti asma, rinitis alergi, alergi makanan, dan dermatitis atopi. ${ }^{6,7}$ Analisis genetik menjelaskan mekanisme genetik yang terjadi dan menemukan kromosom dari penyakit genetik. Beberapa regio kromosom yang terlibat dalam regulasi genetik asma adalah $5 \mathrm{q}, 6 \mathrm{p}, 11 \mathrm{q}$, 12q, 13q dan 14q. ${ }^{6}$ Penelitian multi senter di Amerika Serikat mendapatkan regio lain yang juga penting yaitu 2q, 5p, 11p, 17p, 19q dan 21q. ${ }^{6}$

Faktor lingkungan memegang peranan penting dalam memulai sensitisasi seseorang yang mempunyai bakat alergi. Proses sensitisasi terhadap alergen merupakan proses yang berkelanjutan sejak masa awal kehidupan dapat merupakan faktor lingkungan pranatal dan faktor lingkungan pasca natal. ${ }^{6}$ Faktor lingkungan pranatal termasuk sitokin intra uterin, diet ibu hamil, dan ibu perokok. Sitokin intra uteri membantu perkembangan janin dan melindunginya terhadap penolakan respons sel $\mathrm{T}$ maternal. Sitokin tersebut menggambarkan pola respons Th-1 (IL-2, IFN- $\gamma$, IL12), dan Th-2 (IL-4, IL-5, IL-13) yang saling mempengaruhi dan bekerja dalam satu keseimbangan aktif. Pola respons Th-2 dihubungkan dengan reaksi inflamasi alergi, sedangkan pola respons Th-1 dihubungkan dengan reaksi inflamasi infeksi. Gangguan keseimbangan kearah Th-2 akan mempermudah proses perkembangan alergi. ${ }^{6}$

Penelitian mengenai diet ibu selama hamil masih kontroversial karena beberapa penelitian menunjukkan bahwa dengan diet hipoalergen pada ibu hamil trimester ketiga kehamilan tidak mencegah sensitisasi alergen makanan pada fetus. ${ }^{6}$ Ibu perokok akan membahayakan perkembangan paru bayi baik pada masa sebelum maupun setelah kelahiran, yang berpengaruh terhadap peningkatan risiko terjadinya mengi dan asma kronik serta meningkatkan risiko perkembangan respons $\operatorname{IgE}$ terhadap protein makanan di awal kehidupan. Ibu perokok dapat menyebabkan bayi berat lahir rendah dan ukuran paru kecil yang merupakan faktor risiko untuk terjadinya mengi pada bayi. Selain itu dapat terjadi penurunan fungsi paru neonatus. ${ }^{6}$

Faktor lingkungan pasca natal adalah diet ibu dan bayi, alergen hirup, polutan dalam rumah, dan infeksi. Kejadian alergi makanan sangat tinggi pada awal kehidupan dan mulai menurun setelah usia 3 tahun. Alergi makanan selanjutnya akan berkembang menjadi alergi saluran nafas dan asma. Modifikasi diet dengan merestriksi bahan makanan yang bersifat alergenik selama beberapa tahun pertama kehidupan dapat dilakukan untuk mencegah timbulnya alergi terhadap makanan. ${ }^{7}$ Hal ini berbeda dengan restriksi diet ibu selama kehamilan karena tidak begitu membantu mengurangi risiko terjadinya penyakit alergi pada bayi. Pemberikan ASI untuk mengurangi risiko atopi dan asma ternyata tidak bisa memproteksi anak dari atopi dan asma. ${ }^{8}$

Pajanan dengan alergen hirup saat kelahiran berpengaruh terhadap perkembangan alergi pada anak. Bayi yang lahir pada musim semi mempunyai risiko alergi terhadap birch dan serbuk bunga rumput, sedangkan bayi yang lahir pada musim semi mempunyai risiko berkembangnya alergi terhadap ragweed. ${ }^{1}$ Di Eropa asma lebih sering terjadi pada anak-anak yang lahir pada musim gugur.

Penelitian di Amerika Serikat dan beberapa negara lain di dunia membuktikan bahwa ada hubungan antara alergi terhadap debu rumah dan asma pada anak. Kontrol terhadap lingkungan dengan mengurangi paparan debu rumah mengurangi risiko terjadinya asma. Sporik dan kawan-kawan melakukan penelitian prospektif mengukur kadar protein kutu debu rumah di Inggris dan didapatkan bahwa derajat paparan terhadap protein debu rumah selama masa bayi mempercepat timbulnya gejala asma pada anak. ${ }^{7}$ Polutan sangat berperan terhadap kejadian asma dan rinitis alergi. Polutan yang berperan adalah asap rokok, baik secara aktif maupun secara pasif. Peran polutan outdoor terhadap kejadian asma dan rinitis alergi masih kontroversial. ${ }^{6}$ 
Infeksi oleh Respiratory syncytial virus (RSV) mempermudah terjadinya alergi dan meningkatkan risiko berkembangnya penyakit asma. ${ }^{6,7,9,10}$ Sebaliknya infeksi bakteri yang akan memperkuat respons Th-1 mengurangi risiko terjadinya sensitisasi alergi. ${ }^{6}$ Data dari Afrika menyatakan bahwa infeksi campak pada masa anak menurunkan risiko sensitisasi. ${ }^{6}$

\section{Asma}

Definisi asma pada anak masih controversial, bervariasi tergantung pada tujuan dan memasukkan pandangan dari ahli epidemiologi, klinisi, ahli imunologi, ahli fisiologi, dan ahli patologi. ${ }^{11}$ American Thoracic Society (ATS) memperkenalkan asma sebagai suatu bronkokonstriksi dan hiperreaktivitas bronkus.

Definisi asma menurut Global Initiative in Asthma (GINA) menyatakan bahwa asma adalah gangguan inflamasi kronik saluran napas dengan banyak sel yang berperan, khususnya sel mast, eosinofil, dan limfosit T. Pada individu yang rentan inflamasi ini menyebabkan episode mengi yang berulang, sesak napas, rasa dada tertekan, dan batuk khususnya pada malam atau pada dini hari. Gejala ini biasanya berhubungan dengan penyempitan jalan napas yang luas dan bervariasi yang paling tidak sebagian bersifat reversibel baik secara spontan maupun dengan pengobatan. Inflamasi ini juga berhubungan dengan hiperreaktivitas jalan napas terhadap berbagai rangsangan. ${ }^{12,13}$

Pedoman Nasional Asma anak menggunakan batasan yang praktis dalam membentuk batasan operasional asma pada anak oleh UKK Pulmonologi IDAI (Ikatan Dokter Anak Indonesia) yaitu mengi berulang dan/atau batuk persisten yang timbul secara episodik, cenderung pada malam hari (nokturnal), musiman, mempunyai faktor pencetus diantaranya aktivitas fisik, bersifat reversibel baik secara spontan maupun dengan pengobatan, dan terdapat riwayat asma atau atopi lain pada pasien/ keluarganya. ${ }^{14}$

\section{Patogenesis Asma}

Inflamasi jalan nafas pada asma alergi telah diketahui dengan baik. Terdapat beberapa langkah pada evolusi inflamasi jalan napas. Dimulai dari sensitisasi primer diikuti penentuan fenotipe alergi dari respons imun yang akhirnya terlokalisasi di jalan napas.
Terjadinya pajanan yang berulang akan mengaktivasi sel yang sudah tersensitisasi memproduksi mediator yang menimbulkan spasme bronkus dan inflamasi kronik. ${ }^{15}$ Pada tingkat sel tampak bahwa setelah terjadi pajanan alergen serta rangsang infeksi maka sel mast, limfosit, dan makrofag akan melepas faktor kemotaktik yang menimbulkan migrasi eosinofil dan sel radang lain. Pada tingkat molekul terjadi pelepasan berbagai mediator serta ekspresi serangkaian reseptor permukaan oleh sel yang saling bekerja sama tersebut yang akan membentuk jalinan reaksi inflamasi. Pada orkestrasi proses inflamasi ini sangat besar pengaruh sel Th sebagai regulator penghasil sitokin yang dapat memacu pertumbuhan dan maturasi sel inflamasi alergi. Pada tingkat jaringan akan tampak kerusakan epitel serta sebukan sel inflamasi sampai submukosa bronkus, dan mungkin terjadi rekonstruksi mukosa oleh jaringan ikat serta hipertropi otot polos. ${ }^{16}$

\section{Penyakit alergi saluran napas lain}

\section{Rinitis alergi dan asma}

Rinitis alergi (RA) secara klinis didefinisikan sebagai gangguan fungsi hidung setelah pajanan alergen melalui inflamasi yang diperantarai $\operatorname{IgE}$ pada mukosa hidung. ${ }^{17}$ Interaksi antara alergen dan IgE akan menyebabkan pelepasan mediator sehingga terjadi reaksi inflamasi yang akan menyebabkan gejala klinis yang khas yaitu bersin, hidung beringus, hidung gatal, dan sumbatan hidung.

Rinosinusitis kronik sering bersamaan dengan asma, dipercaya merupakan proses peradangan yang diperani oleh eosinofil dan epitel saluran napas. Eosinofil diperkirakan merusak epitelium dengan mengeluarkan sitokin dan proinflamasi protein sehingga terjadi pengrusakan epitel, lepasnya sitokin dan kemokin yang akan menarik eosinofil untuk memulai terjadinya suatu aksi dan reaksi hebat dan menimbulkan inflamasi. ${ }^{4}$

Hubungan asma dan rinitis alergi telah banyak didiskusikan oleh para peneliti. Data epidemiologi memperlihatkan bahwa rinitis alergi dan asma sering timbul bersamaan. Penelitian imunologi menunjukkan bahwa asma dan rinitis sering terdapat bersama-sama. Gejala hidung dilaporkan terjadi pada 28 hingga 78\% pasien asma dibandingkan dengan 5 hingga $20 \%$ pada masyarakat umum. Demikian pula asma ditemukan 
sampai 38\% dari pasien rinitis alergi, jauh lebih tinggi dari prevalens pada masyarakat luas yang hanya 3 hingga $5 \%{ }^{18}$ Guerra dan kawan-kawan ${ }^{19}$ pada penelitian terhadap orang dewasa mendapatkan pasien rinitis dengan atopi dan tanpa atopi mempunyai risiko untuk menderita asma tiga kali dan risiko asma lima kali lebih pada pasien rinitis dengan kadar IgE yang tinggi. Mullarkey dkk, menilai 142 pasien rinitis dan menemukan bahwa 58\% pasien rinitis alergi musiman disertai asma. ${ }^{20}$ Pengobatan terhadap rinitis alergi menurunkan kunjungan pasien ke gawat darurat atau dirawat karena asma dibandingkan dengan rinitis alergi yang tidak diobati. ${ }^{21}$ Allergic rhinitis and its infant on asthma (ARIA) merekomendasikan pasien dengan RA persisten sebaiknya dievaluasi secara seksama untuk mengetahui adanya asma melalui riwayat penyakit, pemeriksaan paru dan jika mungkin dilakukan penilaian obstruksi aliran udara sebelum dan sesudah pemberian bronkodilator. Pasien dengan asma sebaiknya dievaluasi secara seksama (melalui riwayat penyakit dan pemeriksaan fisis) untuk mengetahui adanya rinitis asma. ${ }^{17}$

\section{Sinusitis}

Fungsi sinus normal berhubungan dengan tiga faktor yaitu tulang sinus yang utuh berbentuk tubular yang sangat sempit, fungsi silia dari epitel, menimbulkan obstruksi ostial yang menyebabkan menurunnya ventilasi sinus dan mengganggu drainase. Faktor yang mengganggu fungsi silia adalah, udara dingin dan kering, perubahan mukus seperti pada kistik fibrosis, zat kimia dan obat, infeksi virus dan kelainan anatomi struktur silia. Mukus diproduksi secara konstans dalam sinus, juga selama sinusitis akut dan kronis dikeluarkan oleh silia melalui ostia normal. ${ }^{22}$

Sinusitis merupakan komplikasi infeksi saluran napas atas, rinitis alergi, polip hidung, dan kelainan lain yang menimbulkan sumbatan hidung. Sinusitis akut atau kronis dapat memprovokasi terjadinya asma. ${ }^{8}$ Selama awal abad ke-20 dicatat tingginya insidens sinusitis pada anak-anak ataupun pasien dewasa. Pada beberapa penelitian telah diketahui insidens radiografi sinus yang abnormal pada anak dengan mengi yang menetap. Pasien asma mempunyai foto sinus yang abnormal antara $31 \%$ dan $53 \% .^{18}$

Sinusitis didefinisikan sebagai inflamasi dari mukosa sinus paranasal yang disebabkan oleh proses infeksi atau bukan infeksi. Sinusitis akut dapat didiagnosis dengan beberapa kriteria mayor dan minor yang menetap untuk masa yang lebih lama dari infeksi saluran napas atas oleh virus yang biasanya lebih dari 7 hari (Tabel. 1). ${ }^{23}$

Tabel 1. Diagnosis klinis sinusitis

\begin{tabular}{|c|c|c|c|}
\hline \multirow{3}{*}{$\begin{array}{l}\text { Diagnosis } \\
\text { Gejala dan tanda }\end{array}$} & \multicolumn{3}{|c|}{ Kriteria } \\
\hline & \multirow{2}{*}{$\begin{array}{l}\text { Mayor } \\
\text { Sekret hidung yang purulen } \\
\text { Sekret faring yang purulen } \\
\text { Batuk }\end{array}$} & \multicolumn{2}{|c|}{ Minor } \\
\hline & & $\begin{array}{l}\text { Edem praorbita } \\
\text { Nyeri pada wajah } \\
\text { Nyeri pada gigi } \\
\text { Nyeri menelan } \\
\text { Mengi }\end{array}$ & $\begin{array}{l}\text { Nyeri kepala } \\
\text { Nyeri telinga } \\
\text { Nafas berbau } \\
\text { Demam }\end{array}$ \\
\hline \multirow[t]{2}{*}{ Diagnosis } & $\begin{array}{l}\text { Gambaran radiologi Water's terdapat opafikasi, } \\
\text { air fluid level atau penebalan mukosa } 50 \% \text { dari } \\
\text { antrum }{ }^{3}\end{array}$ & \multicolumn{2}{|c|}{$\begin{array}{l}\text { Pemeriksaan sitologi nasal neutrofil atau } \\
\text { bakterimia }\end{array}$} \\
\hline & $\begin{array}{l}\text { Sintigrafi korona terdapat penebalan mukosa } \\
\text { atau opafikasi sinus }\end{array}$ & \multicolumn{2}{|c|}{ Pemeriksaan ultrasonografi } \\
\hline
\end{tabular}

Dikutip dari: Shapiro GG,Rechelefsky GS. ${ }^{23}$

kualitas sekresi yang diperlukan untuk fungsi normal dari silia. Faktor-faktor yang mengganggu fungsi sinus yaitu infeksi virus dan inflamasi alergi sering
Diagnosis klinis

- Gejala dan tanda: 2 kriteria mayor atau 1 mayor dan 2 kriteria minor 
- Pemeriksaan diagnostik: 1 mayor = konfirmasi, 1 minor $=$ menyokong

Diagnosis sinusitis kronik ditegakkan bila gejala tersebut lebih dari 3 bulan dengan atau tanpa membutuhkan terapi antibiotik. ${ }^{22}$

\section{Hubungan antara asma dan penyakit alergi saluran napas lain}

Beberapa kemungkinan mekanisme penyebab yang dapat menerangkan hubungan antara asma dengan rinitis alergi dan sinusitis umumnya hampir sama, yaitu refleks nasobronkial/rinosinobronkial, kegagalan fungsi hidung, sekresi post nasal, absorbsi sistemik mediator inflamasi, dan konsep united airways disease. . $^{2,25,26}$

Refleks nasobronkial terjadi karena iritasi pada hidung, alergen atau rangsangan dingin yang dapat menyebabkan spasme bronkus yang terjadi melalui refleks saraf akibat iritasi atau stimulasi ganglion hidung. ${ }^{26,27}$ Rolla G dkk seperti yang dikutip dari Coren ${ }^{18}$ menyatakan sinusitis kronik dapat menginduksi hiperrespons bronkial melalui refleks bronkofaringeal. Pada penelitian tersebut dari 24 pasien sinusitis kronik tanpa asma terdapat 19 pasien yang mempunyai hiperrespons saluran napas bawah terhadap inhalasi histamin. Reaktivitas jalan napas sangat berhubungan dengan lamanya sinusitis, meningkatnya eosinofil pada cairan hidung dan meningkatnya densitas saraf submukosa faring. Coren berspekulasi bahwa sinusitis kronik dapat menimbulkan inflamasi sekunder faring karena terdapatnya peningkatan densitas saraf. Iritan saluran napas dapat mengaktivasi refleks yang berasal dari faring dan menimbulkan spasme bronkus. ${ }^{18}$ Refleks rinosinobronkial secara umum dipercaya merangsang reseptor di hidung, nasofaring, dan mungkin sinus menimbulkan spasme bronkus. ${ }^{28}$

Inhalasi melalui mulut meningkat pada sinusitis dan rinitis alergi karena sumbatan hidung. Fungsi hidung dalam hal membersihkan, menghangatkan, dan melembabkan udara yang masuk gagal sebagian atau keseluruhannya. Kegagalan ini akan menyebabkan spasme bronkus karena bronkus lebih responsif. ${ }^{24}$ Sekret post nasal yang terdapat pada sinusitis dan rinitis mengandung banyak mediator inflamasi akan merangsang terjadinya batuk dan mengi. Percobaan pada binatang memperlihatkan bahwa sekresi dari belakang hidung membawa sitokin dan mediator dari nasofaring ke jalan napas bawah menyebabkan inflamasi dan bronkokonstriksi. ${ }^{24}$ Absorbsi sistemik mediator inflamasi atau faktor kemotaktik yang dilepaskan mastosit atau eosinofil seperti histamin, leukotrin, dan platelet activating factor (PAF) dapat meningkatkan hiperreaktivitas bronkus. ${ }^{24,26}$

\section{Keterlibatan saluran napas atas dan saluran napas bawah}

Konsep united airway diseases menyatakan bahwa proses inflamasi akan melibatkan saluran napas atas dan bawah. ${ }^{25}$ Asma sering bersamaan dengan rinitis didukung oleh beberapa faktor seperti karakteristik epidemiologi, patologi, dan pendekatan terapi umum untuk rinitis dan asma. Teori adesi rinovirus menyatakan kemungkinan hubungan antara inflamasi alergi hidung dengan asma adalah ekspresi intracellular adhesion molecul (ICAM-I) di mukosa hidung yang meningkat melalui pajanan alergen dan juga diekspresikan walaupun pada pasien RA tanpa gejala. Dengan meningkatnya ekspresi ICAM-I maka kemungkinan infeksi saluran napas atas oleh rhinovirus akan lebih sering karena ICAM-I merupakan reseptor untuk rhinovirus. Infeksi Rhinovirus penting dalam presipitasi eksaserbasi asma. ${ }^{15}$ Konsep ini belum sepenuhnya diterima, tetapi terminologi rinobronkitis alergi telah diterima sebagai hubungan asma dan rinitis. ${ }^{15,29}$ Penelitian oleh Brinke dan kawan kawan terhadap 89 pasien dewasa memperlihatkan hubungan ketebalan mukosa sinus paranasal yang diperiksa dengan sken sinus paranasal dan peradangan bronkus pada asma berat. Apakah penyakit sinus secara langsung mempengaruhi intensitas inflamasi bronkus masih belum bisa dijawab. ${ }^{28}$

\section{Inflamasi pada rinitis, sinusitis, dan asma}

Histopatologi asma mempunyai beberapa gambaran kunci, yaitu peningkatan sel-sel eosinofil, limfosit, dan sel mast; edema mukosa, meningkatnya jumlah sel goblet dan mukus yang diproduksi, deskuamasi epitel, hiperplasi otot polos dan konstriksi. Gambaran ini juga terdapat pada rinitis alergi dan sinusitis kronik, kecuali perubahan otot polos dan deskuamasi epitel. Dasar imunologi pada ketiga kelainan ini juga sama, sel limfosit Th-2 yang predominan pada jaringan dan pelepasan sejumlah sitokin termasuk interleukin IL3, IL-4, IL-5, IL-13, GM-CSF, TNF- $\alpha$, RANTES, dan eotaksin. ${ }^{19,23}$ Sel Th-2 memegang peranan penting 
dalam rinitis alergi dan asma, baik pada fase sensitisasi terhadap antigen, membantu sel B dalam mensintesis $\operatorname{IgE}$, dan sebagai bagian dari kaskade inflamasi. ${ }^{23}$

\section{Kesimpulan}

Berbagai penelitian asma pada anak memperlihatkan suatu pola hubungan antara proses sensitisasi alergi dengan perkembangan dan perjalanan penyakit alergi yang berawal dari alergi saluran cerna, alergi kulit dan berakhir dengan alergi saluran napas. Penyakit alergi yang sering bersamaan dengan asma adalah rinitis alergi dan sinusitis. Sampai sekarang belum jelas bagaimana mekanisme hubungan asma dengan rinitis alergi maupun hubungan asma dengan sinusitis. Beberapa teori yang menerangkan mekanisme hubungan ini adalah terdapatnya refleks nasobronkial, meningkatnya inspirasi melalui mulut, aspirasi sekret post nasal, melalui inflamasi saluran napas atas dan bawah yang saling mempengaruhi, serta konsep united airways disease.

\section{Daftar Pustaka}

1. Akib AAP. Perjalanan alamiah penyakit alergi dan upaya pencegahannya. Dalam: Akib AAP, Tumbelaka AR, Matondang CS, penyunting. Pendekatan imunologis berbagai penyakit alergi dan infeksi. Naskah lengkap PKB Ilmu Kesehatan Anak XLIV.Jakarta:FKUI, 2001. h. 117-27.

2. Slavin GR. Asthma and sinusitis. J Allergy Clin Immunol 1992;90:534-7.

3. Brinke AT, Grootendorst DC, Schmidt JT, Bruine FT, van Buchem MA, Sterk PJ, dkk. Chronic sinusitis in severe asthma is related to sputum eosinophilia. J Allergy Clin Immunol 2002;109:621-6.

4. Bresciani M, Paradis L, Des roches A, Vernhet H, Vachier I, Godard P dkk. Rhinosinusitis in severe asthma. J Allergy Clin Immunol 2001;107:73-80.

5. Sundaru H. United airway diseases: Konsep baru penyakit alergi saluran napas. Disampaikan pada Simposium sehari United Airway Disease. Jakarta, Mei 2003.

6. Samet JM, Wiesch DG, Ahmed IH. Pediatric asthma; epidemiology and natural history. Dalam: Naspitz CK, Szeler SJ, Tinkelman D Warner JO, penyunting. Textbook of pediatric asthma. London: Martin Dunitz, 2001. h. 35-66.
7. Gern JE, Lemanske RF. Pediatric allergy can it be prevented? Immul Allergy Clin North Am 1999;19:233-52.

8. Sears MR, Greene JM, Willan AR, Taylor DR, Flannery EM, Cowan JO, dkk. Long-term relation between breastfeeding and development of atopy and asthma in children and young adults: a longitudinal study. Lancet 2002;360:901-07.

9. Heymann PW, Zambrano JC, Rakes GP. Virus induced wheezing in children. Respiratory syncytial virus bronchiolotis (RSV) and rhinovirus. Immunol Allergy Clin North Am 1998;18:35-47.

10. Sigur N, Bjarnason R, Sigurbergsson F, Kjellman B. Respiratory Syncytial Virus in infancy as an important risk factor for asthma and allergy at age 7. Am J Respir Crit Care Med 2000;161:1501-7.

11. Parkin P, Goggin N. Asthma. Dalam: Feldmen E, penyunting. Evidence based pediatrics. London: BC Decker Inc, 2000. h. 123-53.

12. Sears MR. Epidemiology of childhood asthma. Lancet 1997;350:1015-20.

13. Global initiative for asthma. Global strategy for asthma management and prevention. 2002

14. UKK Pulmonologi PP IDAI. Pedoman Nasional Penanganan Asma Anak. Disampaikan pada Temu ahli respirologi anak IV, Medan, 5 April 2003.

15. Warner JO. Asthma-basic mechanism. Dalam: Naspitz CK, Szeler SJ, Tinkelman D Warner JO, penyunting. Textbook of pediatric asthma. London: Martin Dunitz, 2001. h. 20-33.

16. Akib AAP. Asma pada anak. Sari Pediatri 2002; 4:7882.

17. Bosquet J, Cauwenberge P, Khaled N, Maesano IA, Bachert C, Cagnani CB, dkk. Management of allergic rhinitis and its impact on asthma initiative (ARIA). A pocket guide for physicians and nurses. ARIA workshop report 2001:1-13.

18. Corren J, Rachelefsky. Upper airways disease and asthma. Dalam: Naspitz CK, Szeler SJ, Tinkelman D Warner JO, penyunting. Textbook of pediatric asthma. London: Martin Dunitz, 2001. h. 223-35.

19. Guerra S, Sherrill DL, Martinez FD, Barbee RA. Rhinitis as an independent risk factor for adult onset asthma. J Allergy Clin Immunol 2002;109:419-25.

20. Lack G. Pediatric allergic rhinitis and comorbid disorders. J Allergy Clin Immunol 2001;108:S9-15.

21. Peter JC, Neslusan C, Crown WH, Torres A. Treating allergic rhinitis in patients with comorbid asthma: the risk of asthma-related hospitalizations and emergency department visits. J Allergy Clin Immunol 2002;109:57-62. 
Sari Pediatri, Vol. 7, No. 1, Juni 2005

22. Giebink GS. Childhood sinusitis: pathophysiology, diagnosis and treatment. Pediatr Infect Dis J 1994;13:S55-8.

23. Shapiro GG, Rachelefsky GS. Introduction and definition of sinusitis. J Allergy Clin Immunol 1992;90:417-18.

24. Campanella SG, Asher MI. Current controversies: sinus disease and the lower airways. Pediatr Pulmonol 2001;31:165-172.

25. ARIA workshop group. 6 Comorbidity and complications. J Allergy Clin Immunol 2001;108:198-207.

26. Irawati N. Penyakit penyerta pada rinitis alergi. Disampaikan pada Simposium sehari United Airway
Disease. Jakarta, Mei 2003.

27. American Thoracic Society Workshop. Immunobiology of asthma and rhinitis. Pathogene factors and therapeutic options. Am J Respir Crit Care Med 1999;160:1778-87.

28. Brinke AT, Grootendorst DC, Schmidt, Bruine FT, Buchem MA, Strek PJ, dkk. Chronic sinusitis in severe asthma is related to sputum eosinophilia. J Allergy Clin Immunol 2002;109:621-6.

29. Leynaert B, Neukirch F, Demoly P, Bousquet J. Epidemiologic evidence for asthma and rhinitis comorbidity. J Allergy Clin Immunol 2000;106:201-5. 